\title{
Immunohistochemistry of Atlantic cod larvae Gadus morhua experimentally challenged with Vibrio anguillarum
}

\author{
Ane Rebecca Engelsen, Nina Sandlund*, Ingrid Uglenes Fiksdal, Øivind Bergh
}

Institute of Marine Research, PO Box 1870 Nordnes, 5817 Bergen, Norway

\begin{abstract}
Farming of Atlantic cod Gadus morhua is one of the most rapidly growing sectors of Norwegian aquaculture. Classical vibriosis caused by Vibrio anguillarum is a problem in cod aquaculture. To prevent disease outbreaks, a thorough understanding of the infection route and the impact of the bacteria on the host is important. The intestinal tract, skin and gills have all been proposed as routes of entry for bacterial infections such as vibriosis. We aimed to further develop understanding of $V$. anguillarum serotype $\mathrm{O} 2 \alpha$ infections in cod larvae by elucidation of a possible route of entry, the pattern of infection and its histopathology. Cod eggs were transferred to a 24-well polystyrene multi-dish with $2 \mathrm{ml}$ of sterile aerated $80 \%$ (28\% salinity) seawater. Challenge doses were $10^{4}$ and $10^{6} \mathrm{CFU} \mathrm{ml}{ }^{-1}$. Unchallenged larvae were used as controls. Larvae for immunohistochemical examination were sampled daily from each group. In most of the larvae, either no or very few bacteria were observed. Typical findings were clusters of bacteria in the spaces between the primary gill lamellae. None of these bacteria seemed to have adhered to the gills. Intestines of 3 out of 161 larvae examined contained positively immunostained bacteria. Some bacteria appeared attached to the microvilli, but none was observed inside epithelial cells. Only 2 larvae from the low-challenge dose group showed clear signs of histopathology, which occurred in the intestine. It is not possible to draw any conclusions regarding the portal of entry.
\end{abstract}

KEY WORDS: Vibrio anguillarum - Cod larvae · Immunohistochemical studies · Challenge experiment Resale or republication not permitted without written consent of the publisher

\section{INTRODUCTION}

The Atlantic cod Gadus morhua is an economically important species on the Norwegian coast, and cod fisheries have long traditions (Svåsand et al. 2004). Declining wild cod stocks, reduced catch quotas and thus rising prices have turned Atlantic cod farming into one of the most rapidly growing sectors of Norwegian aquaculture. A most important challenge to the creation of profitable cod farms has been the lack of large-scale fry production. It is not merely the lack of fry available, but also the instability of production and quality of the larvae produced that cause problems. The industry lacks a standardized production method, which may be one reason for the wide differences among larval groups (Svåsand et al. 2004). Infectious bacterial diseases have always been an important aspect in aquaculture. The high mortality of the larval stages is still a major bottleneck, partly because of infectious diseases (Vadstein 1997, Bricknell \& Dalmo 2005). Compared to salmonids, Atlantic cod is poorly developed at hatching and undergoes a long larval period before metamorphosis (Kjørsvik et al. 1991, Pedersen \& Falk-Petersen 1992). During these stages, the fry are vulnerable to bacterial infections (Bricknell et al. 2006). Several important bacterial diseases affect Atlantic cod (reviewed by Samuelsen et al. 2006). Classical vibriosis caused by Vibrio anguillarum may be a problem for both adult fish and larvae. V. anguillarum and closely related bacterial species have been identified in many different marine habitats (reviewed by Thompson et al. 2004). This implies that the bacterium is native in these environments and eradication of the disease is not possible. At least $23 \mathrm{O}$ serotypes 
of $V$. anguillarum have been described (Pedersen et al. 1999). In salmonids, the main $V$. anguillarum serotypes that cause disease are $\mathrm{O} 1$ and $\mathrm{O} 2 \alpha$, while the serotypes $\mathrm{O} 2 \alpha$ and $\mathrm{O} 2 \beta$ are most commonly associated with cod (Larsen et al. 1994, Pedersen et al. 1999). Both $O 2 \alpha$ and $O 2 \beta$ have been isolated from diseased cod, but O2 $\beta$ seems predominant (Bricknell et al. 2006). Some $V$. anguillarum isolates that cause disease in cod belong to a new sero-subtype, as shown by serological, biochemical and genotypical differences from other known serotypes (Mikkelsen et al. 2007). Cod larvae have a fully competent immune system around 2 to 3 mo after hatching (Schrøder et al. 1998). Hence, conventional vaccination prior to this age will probably not have a positive effect. Both exterior and internal surfaces (skin, gills and intestinal tract) have been proposed as entry portals for pathogenic bacteria (Baudin Laurencin \& Germon 1987, Kanno et al. 1989, Smith et al. 2004). Studies involving intestinal mucus are frequently used to test growth, adherence and attachment of pathogenic bacteria (Garcia et al. 1997, Vine at al. 2004, Yan et al. 2007). The entry portal for $V$. anguillarum has been debated. The gut may be the initial site of infection in turbot larvae Scophthalmus maximus (Grisez et al. 1996), a proposition supported by experiments of O'Toole et al. (1999) and Olsson et al. (1996). V. anguillarum has been detected in cod larvae fed rotifers enriched with commercial products (Korsnes et al. 2006), and it is possible that live feed such as rotifers and Artemia spp. may be vectors for opportunistic bacteria that infect cod larvae. Spanggaard et al. (2000) found that the external surfaces (skin and fins) of rainbow trout were important sites for the attachment and proliferation of $V$. anguillarum. Bath challenge experiments with unfed cod yolk sac larvae have caused high mortalities (N. Sandlund \& Ø. Bergh unpubl. data), suggesting that the skin is an important entry portal . The gills may also be an entry portal for $V$. anguillarum. In an immersion challenge trial with rainbow trout Salmo gairdneri, Baudin Laurencin \& Germon (1987) suggested that the gills were the initial sites of infection. However, due to early observations of bacteria in the anterior and posterior intestine, they concluded that contamination by oral or anal routes was also a possibility. Inconclusive results were also found by Olsson et al. (1996). When they inoculated $V$. anguillarum directly on the gills of turbot, they were unable to recover the pathogen from the spleen. The aim of our study was to further understanding of $V$. anguillarum serotype $\mathrm{O} 2 \alpha$ infections in cod larvae by (1) using immunohistochemical methods to identify a possible portal entry route, (2) observing the pattern of infection and the tissues types infected, and (3) describing the histopathology.

\section{MATERIALS AND METHODS}

Broodstock, eggs and larvae. Cod Gadhus morhua eggs were provided by the commercial hatchery Sagafjord in Hordaland County, western Norway $\left(59^{\circ} 45^{\prime} \mathrm{N}, 5^{\circ} 29^{\prime} \mathrm{E}\right)$. The broodstock originated from the area outside Bømlo/Halsnøy in the same county. The broodfish were kept in $40 \mathrm{~m}^{3}$ tanks, each containing 60 to 80 fish that spawned naturally. The fertilized eggs were collected and disinfected with glutardialdehyde (300 ppm) for 10 min before incubation in black conical 1501 tanks. The average temperature was 6.5 to $7^{\circ} \mathrm{C}$. A flow-through system provided 2 to $31 \mathrm{~min}^{-1}$ of aerated water.

Bacterium. The bacterium used in this challenge experiment was Vibrio anguillarum strain HI-610 serotype $\mathrm{O} 2 \alpha$, originally isolated from cod suffering from vibriosis at the Parisvatnet research facility in Øygarden near Bergen, Hordaland County. This bacterium was previously serotyped according to Knappskog et al. (1993). Bacteria were stored at $-80^{\circ} \mathrm{C}$ in a $20 \%$ glycerol/marine broth (MB) (Difco 2216) stock. They were incubated at $15^{\circ} \mathrm{C}$ and grown on petri dishes with Difco 2216 marine agar (MA) for $48 \mathrm{~h}$. Colonies were transferred to Erlenmeyer flasks containing $50 \mathrm{ml}$ of MB (Difco 2216) and shaken at $80 \mathrm{rpm}$ in a shaking incubator (INFORS AG) for $48 \mathrm{~h}$. Thirty $\mathrm{ml}$ of each bacterial culture were harvested by centrifugation (Heraeus Sepatech Megafuge $1.0 \mathrm{R}$ ) at $2772 \times g$ for $10 \mathrm{~min}$ at $4^{\circ} \mathrm{C}$, washed twice in $30 \mathrm{ml}$ phosphatebuffered saline (PBS) and resuspended in $30 \mathrm{ml}$ PBS. The bacterial concentration was determined by counting cells in a Hawksley counting chamber. The bacterial suspension was examined under a microscope in order to verify that the bacterium were still viable prior to challenge.

Challenge experiment. Eggs were randomly selected, and individual eggs were transferred to separate wells in a 24-well polystyrene multi-dish (Nunc) containing $2 \mathrm{ml}$ of sterile aerated $80 \%$ (28\% salinity) seawater. They were challenged with Vibrio anguillarum strain HI-610 on the same day by adding $100 \mu \mathrm{l}$ of bacterial suspension to each well. All eggs hatched successfully after $48 \mathrm{~h}$. This experiment comprised 3 groups of larvae. The control group consisted of unchallenged larvae; Groups I and II were challenged with $10^{4}$ colony-forming units (CFU) $\mathrm{ml}^{-1}$ and $10^{6} \mathrm{CFU} \mathrm{m \textrm {m } ^ { - 1 }}$, respectively. Three plates were used for each group, giving a total number of 72 larvae in each treatment group. Dead larvae were counted daily. To provide material for the immunohistological examinations, 3 extra plates with larvae for all 3 groups were prepared. The first samples were taken on Day 4 after challenge and every following day until the experiment was terminated. Day 16 after 
hatching was the last sampling day in Group I and the control group. Because all the larvae needed to be sampled alive, no samples were taken from Group II after Day 14 due to the high mortality. Between 2 and 5 larvae were sampled daily from each group, and a total of 161 larvae were analyzed in this study. The experiment ran $21 \mathrm{~d}$.

Antisera. All antisera against Vibrio anguillarum HI 610 were produced according to the method of Oeding (1957) and absorbed by the method of Knappskog et al. (1993). Due to availability limitations, 2 different batches of antiserum were used to perform the immunohistochemical analyses. The antisera were absorbed against serotype O2 $\beta$ strain HI-618 and serotype O1 strain HI-644, and tested for crossreaction.

Immunohistochemistry. Larval samples were fixed in $4 \%$ phosphate-buffered formaldehyde, dehydrated in ethanol and embedded in paraffin. All the larvae were sectioned at $3 \mu \mathrm{m}$ (Leica Jung Biocut 2035), incubated at $60^{\circ} \mathrm{C}$ for $30 \mathrm{~min}$, dewaxed in xylene (Chemi-Teknik AS), rehydrated in a series of ethanol baths and washed in running water. The absorbed polyclonal rabbit antiserum anti-HI-610 was diluted in Tris-hydroxymethylaminomethane (TRIS)-buffered saline (TBS) with $2.5 \%$ bovine serum albumin (BSA). In order to prevent nonspecific antibody binding, sections were blocked using $5 \%$ BSA in TRIS-buffered formaldehyde for $20 \mathrm{~min}$. An avidine-biotin-alkaline phosphatase complex (ABComplex/AP) reaction kit (DAKO A/S) and New Fuchsin Substrate system (Dako) were used to stain Vibrio anguillarum. A positive staining was evident as red coloration. Shandon's hematoxylin was used for counterstaining, which gave the tissue a blue coloration. At each stage of staining, 2 controls were used. Unchallenged larvae were used as a negative control, and bacterial smears on microscope slides were used as a positive control. The same procedure was used to stain both larvae and bacteria. During the staining procedures, tissue sections and bacterial samples were kept apart to prevent cross-contamination. All incubations were performed at room temperature $\left(20^{\circ} \mathrm{C}\right)$ in a humidity chamber. A Leica DMBE microscope equipped with a Leica Wild MPS52 phototube was used to photograph the tissue sections.

Hematoxylin-erythrosine-saffron (HES) staining. Heated, dewaxed and rehydrated larval sections were stained with hematoxylin, $1 \%$ erythrosine and saffron. These were added through a series of baths in order to stain nuclei, muscle and cytoplasm and connective tissue. This staining was performed to identify histopathology in the larvae.

Statistical analysis of mortality rates. The mortality data were not normally distributed and a non-parametric test was performed. A $2 \times 2$ contingency table analysis was performed in STATISTICA v 7.0 (StatSoft) using a Bonferroni corrected $p$-value $(p<0.00094)$ for multiple independent tests. This was used to test for mortality differences among the treated groups and the control group. Multiple independent tests were used to test differences in mortality rates between the challenged larval groups and the larval control groups, and a Bonferroni correction was applied (to minimize the possibility of a Type II error) (Rice 1989). Because there was only one degree of freedom, Yates correction was applied.

This experiment formed part of a larger challenge experiment. The statistical analyses of mortality rates will therefore be published in a separate article by Sandlund \& Bergh (in press). This article contains only data regarding the control and larval groups exposed to Vibrio anguillarum strain HI-610.

\section{RESULTS}

\section{Cumulative mortality and statistical analysis}

Mortality rates in the control group and Group I were less than 0.15 during the first $12 \mathrm{~d}$ after hatching. At Day 13, there was a rapid rise in Group II mortality (Fig. 1). Cumulative mortality in this group increased between Days 2 and 6 post hatching, stabilized at approximately 0.6 for several days before increasing towards the end of the experiment (Fig. 1). The mortality rates of the control group and Group II were signif-

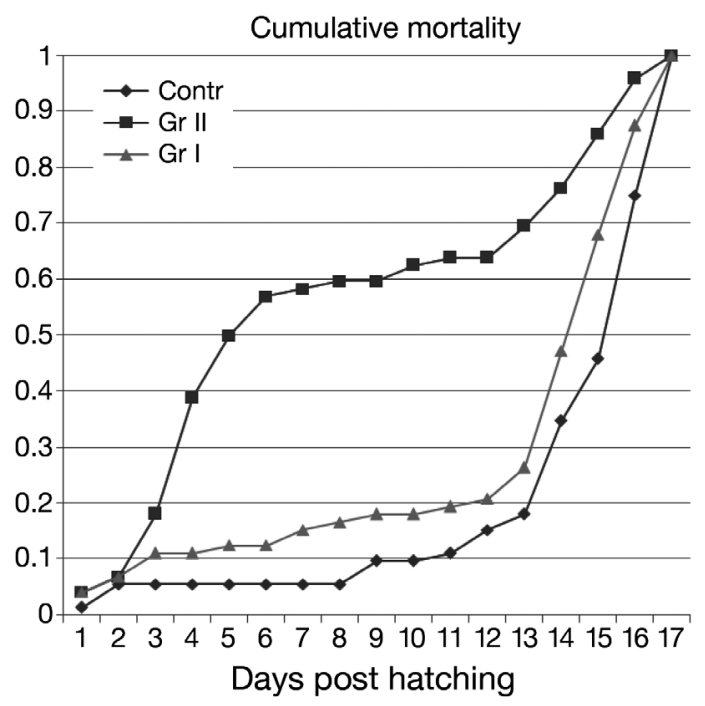

Fig. 1. Gadus morhua. Cumulative mortality of 3 larval groups. Contr: Control group containing larvae not exposed to bacteria; Gr I: Larval Group I challenged with Vibrio anguillarum strain HI-610, dose $10^{4} \mathrm{CFU} \mathrm{ml}{ }^{-1}$; Gr II: Larval Group II challenged with $V$. anguillarum strain HI-610, dose $10^{6} \mathrm{CFU} \mathrm{ml}^{-1}$ 
icantly different $(\mathrm{p}<0.00094$, Bonferonni correction, data not shown), but rates in Group I and the control group were not. Feed was not provided during this experiment; the rise in mortality at the end of the experiment was thus due to starvation.

\section{Immunohistochemistry}

The immunohistochemical studies provided no clear explanations for the portal entry route or for the pathology causing the high mortality. In most of the

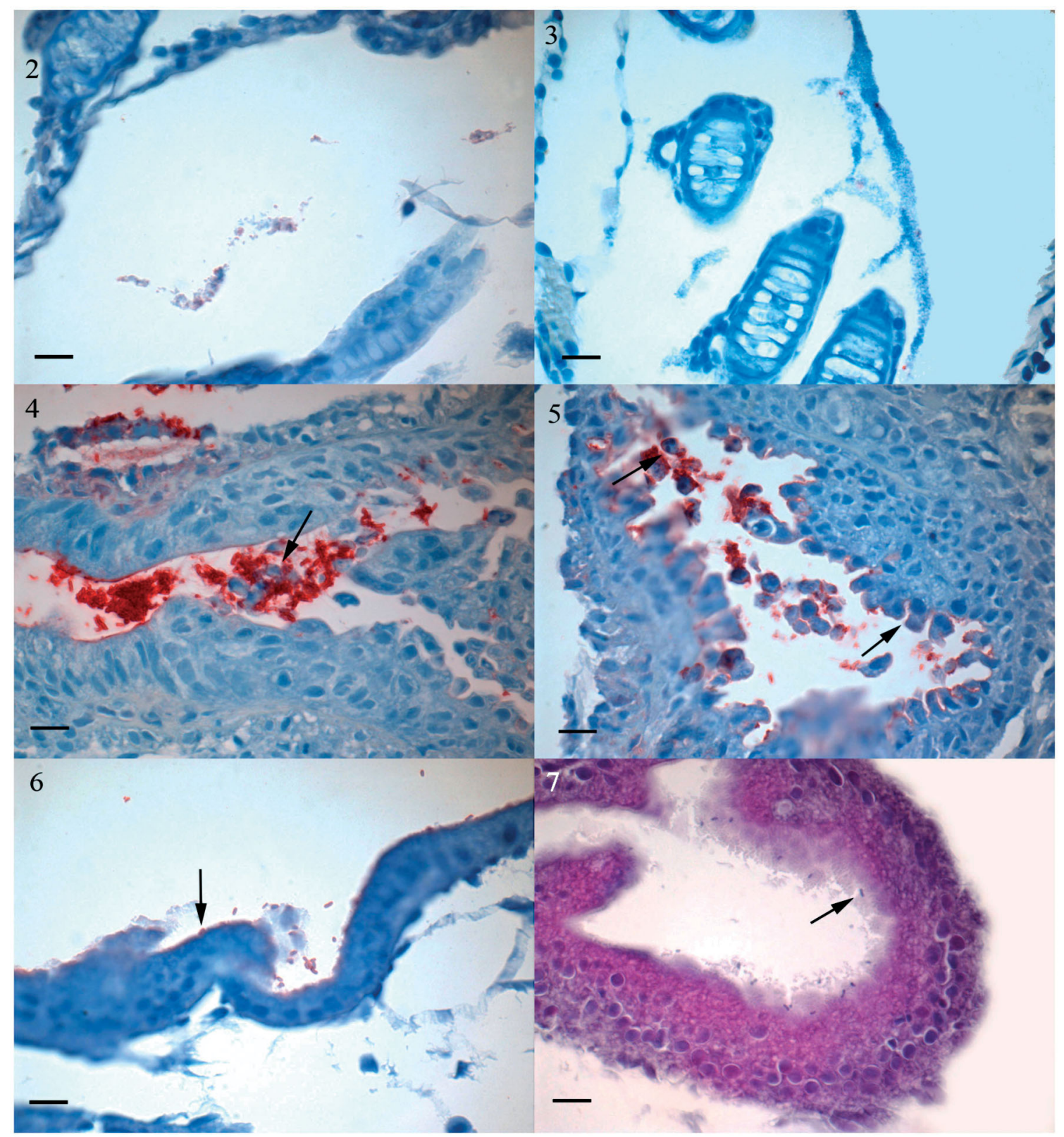

Figs. 2 to 7. Gadus morhua. Figs. 2 to 6: Immunohistochemical staining of larvae (paraffin sections). Avidine-biotin-alkaline phosphatase method, rabbit anti Vibrio anguillarum strain HI-610 serum and Shandon haematoxylin counterstained. Postive immunohistochemistry is visualized by red colour. Counterstaining gives tissue different tones of blue. Fig. 2. Gills of Group I larvae $8 \mathrm{~d}$ post hatching. Bacteria are present in the space between the primary lamellae; some are clearly positively stained red while others show no positive colour. Fig. 3. Gills of Group II larvae $15 \mathrm{~d}$ post hatching. Many bacteria are present, but there is little positive staining. Fig. 4. Intestine of Group II larvae $4 \mathrm{~d}$ post hatching. Large numbers of bacteria are present. Necrotic cells are visible among the bacteria (arrow). Fig. 5. Intestine of Group II larvae $4 \mathrm{~d}$ post hatching. Large numbers of bacteria are present. Necrotic cells are visible among the bacteria (arrows). Fig. 6. Intestine of Group I larvae $4 \mathrm{~d}$ post hatching. Bacteria are present in the lumen and attached to the brush border of the intestine (arrow) but no necrotic cells are visible. Fig. 7. Group I larval intestine $4 \mathrm{~d}$ post hatching stained with hematoxylin erythrosine-saffron. Larvae are the same as in Fig. 4. Bacteria are present (stained violet) in the brush border (arrow), but there is no necrosis. All scale bars $=10 \mu \mathrm{m}$ 
larvae studied, there were very few or no bacteria. Typical findings were clusters of bacteria in the spaces between the primary gill lamellae, but none seemed to have adhered to the gills. However, these clusters were only partially stained or not positively stained at all (Figs. 2 \& 3). Two Group II larvae (Figs. 4 \& 5) and 1 Group I larva (Figs. 6 \& 7) contained stained bacteria in their intestines. Some of the bacteria appear attached to the microvilli, but although interstitial immunostaining was performed, no bacteria were observed inside the cells (Figs. 4 to 6). One Group II larva had more bacteria in the intestine than any of the other larvae (Fig. 4). Except for the 2 Group II larvae (Figs. 4 \& 5), no histopathology was observed in any of the larval groups. Necrotic cells with some pycnotic nuclei (Fig. 5, arrow) and dissolved epithelial cell nuclear membranes occurred in the intestine. Note the rounding and dissociation of the epithelial cells in the brush border (Fig. 5, arrow). Three control group larvae had some bacteria in the space between the primary gill lamellae, but these were not specifically stained (data not shown).

\section{DISCUSSION}

To further understanding of Vibrio anguillarum infections in cod larvae Gadus morhua we investigated a possible entry portal, the pattern of infection, tissue types infected, and we described the histopathology. The results were inconclusive. In spite of the high mortality in the high challenge-dose group, little histopathology was observed in the course of the immunohistochemical examinations. The absence of histopathology also suggests that the disease develops acutely and that the larvae died before any pathological alterations became apparent.

Toxic components associated with and released from metabolized bacterial cells may cause disease. Supernatant from Vibrio anguillarum leads to mortality in turbot Scophthalmus maximus larvae (Planas et al. 2005, 2006). Supernatants of bacterial cultures include extracellular products (ECP) produced by the bacteria. An experimental bath challenge (with typical Aeromonas salmonicida ssp. salmonicida) to turbot and halibut yolk-sac larvae resulted in significant mortality (Bergh et al. 1997). Histological and immunohistochemical examinations of the larvae revealed no evidence of bacteria in affected tissues. Bergh et al. (1997) suggest that the mortality resulted from production of toxic exudates by the bacteria, which may also explain our results with cod larvae. Supporting evidence is provided by Sandlund et al. (2006), who challenged great scallop Pecten maximus larvae with Vibrio pectenicida, but in this case there was histopathology in tissue samples. Furthermore, live and heat-killed $V$. anguillarum are equally lethal when injected into goldfish Carassus auratus (reviewed by Egidius 1987).

Our immunohistochemical examinations revealed clusters of bacteria around the larval gills (Figs. 2 \& 3). These cells were smaller than bacteria found in the larval intestine. We have repeatedly observed that this particular Vibrio anguillarum strain changes size and appearance when grown and transferred from an in vitro to an in vivo environment. The polyclonal antiserum used in this experiment attaches to the bacterial surface lipopolysaccharide (LPS). When bacterial clusters are extremely compact, the form of the LPS may change or become unavailable to the antiserum, preventing positive staining. The bacteria may release LPS when entering the intestine and thus appear larger. However, in view of the near total absence of positive immunostaining of gill-associated bacteria in all the larvae examined, and the fact that fish larvae are not sterile (Verner-Jeffreys et al. 2003), it is likely that other bacteria were present in the larvae.

Suffocation caused by the bacteria around the gill lamellae is another possible explanation of larval death without apparent presence of bacteria. However, oxygen exchange through body surface skin occurs in larvae and juveniles of Atlantic salmon Salmo salar (Wells \& Pinder 1996a,b) and rainbow trout Oncorhynchus mykiss (Rombough 1998). It is likely that cod larvae are similarly capable of exchanging oxygen across the skin. Thus, bacteria clustered around the gills of cod larvae likely did not cause a lack of oxygen or influence mortality. In similar challenges to halibut larvae with Vibrio fischeri, large numbers of bacteria occurred between the gill arches, and there was necrosis in the gill epithelium (Bergh et al. 1992). None of the larvae examined in our experiment had damaged gill tissue, supporting the suggestion that bacteria observed in the gill area did not have any negative effects on the larvae. Moreover, clusters of bacteria also occurred in larval Group I and the control group, in which no bacteriogenic mortality occurred.

Bacterial epiflora may create lethal or sublethal conditions in the environment through excessive oxygen consumption (Hansen \& Olafsen 1989) that affects fish eggs and larvae. However, all of the eggs in our experiment hatched successfully within a period of $12 \mathrm{~h}$, indicating that they were healthy and unaffected by adverse environmental influences. Furthermore, all eggs, and thus all larvae, originated from the same egg bath and were randomly selected. Were potentially unfavorable bacteria or other factors present in the environment, all larval groups would have been affected in the same way.

As mentioned above, bacteria have 3 potential points of entry into the larvae: skin, gills and intestine. The 
mucosa serves as a substrate for bacterial adhesion to fish (Hansen \& Olafsen 1989, Vine et al. 2004). Vibrio anguillarum may have a stronger tendency to adhere to intestinal mucosa than to skin mucosa (Olsson et al. 1996, O'Toole et al. 1999). Conversely, there are suggestions that the skin is a major site of attachment and proliferation for $V$. anguillarum in ayu Plecoglossus altivelis and rainbow trout (Kanno et al. 1989, Spanggaard et al. 2000, respectively). Baudin Laurencin \& Germon (1987) propose that the gills are the initial infection site in rainbow trout Salmo gairdneri. In their experiment, they inspected gills, anterior and posterior intestine and anterior kidney, but did not take skin samples. No cod larvae in our challenge experiment had bacteria associated with the skin.

In our laboratories, Vibrio anguillarum strain HI-610 is commonly used in challenge experiments, and a bath challenge dose of $10^{4} \mathrm{CFU} \mathrm{m} \mathrm{m}^{-1}$ usually causes high mortality (Sandlund \& Bergh in press). However, in the present work, only the high challenge-dose group $\left(10^{6} \mathrm{CFU} \mathrm{\textrm {ml } ^ { - 1 }}\right)$ suffered significantly higher mortality than the control group. There are no obvious explanations for this result. The washing procedure prior to challenge may have stressed the bacteria, resulting in a temporary loss of virulence (Planas et al. 2005). Chemotactic motility mediated by the polar flagellum is essential for virulence of $V$. anguillarum (Milton et al. 1996, O'Toole et al. 1996, Ormonde et al. 2000). However, examination of the bacterial suspension prior to the challenge revealed no lack of motility. The washing procedure used is standardized in our laboratory. In a similar challenge experiment with $V$. anguillarum and Atlantic halibut Hippoglossus hippoglossus yolk-sac larvae, temperature was a controlling factor (Verner-Jeffreys et al. 2003). Low temperature $\left(6^{\circ} \mathrm{C}\right)$ may cause bacteria to multiply slowly inside the larvae, thus lowering fish mortality rates. This was also implied by Larsen (1984). However, cod larvae in our experiment were reared at $7^{\circ} \mathrm{C}$, the temperature used to grow the bacteria prior to challenge. We observed little difference in growth rates at 7 and $15^{\circ} \mathrm{C}$ for this $V$. anguillarum strain. Given our observations of motile bacteria prior to challenge and the fact that high mortality occurred in Group II, we find it unlikely that the washing procedure or temperature contributed significantly to the lack of mortality in the low challenge-dose group.

The decision to keep the larvae alive until the point of starvation was due to the possibility of losing significant data. Thanks to the knowledge obtained in this experiment, future experiments done under similar conditions can be brought to an end at an earlier stage, i.e. until Days 12 to 13 post hatching.

To obtain a valid impression of the histopathology and to avoid post mortem changes, all larvae were sampled live. Sampling when larvae are moribund would be optimal, but practical considerations made it impossible to monitor them so closely. It is probable that most of the larvae in this experiment were sampled before any clear histopathology was present. This might explain the low correspondence between the histological findings and the mortality observed.

Marine fish larvae drink water from Day 1 post hatch (Mangor-Jensen \& Adoff 1987) and thereby ingest bacteria. Fish larvae have an undeveloped stomach at hatching (Kjørsvik et al. 1991). The onset of the acid digestion is a gradual process and the lowering of stomach pH takes 2 to 3 mo in sea bream Sparus aurata larvae (Yúfera et al. 2004). It is likely that larval intestinal $\mathrm{pH}$ in our experiment was similar to that of seawater, which is not low enough to inhibit bacterial growth.

Apart from drinking water, infection of feed is another way of ensuring the presence of bacteria in the intestine. To describe the infection route of Vibrio anguillarum, Grisez et al. (1996) orally fed infected Artemia sp. nauplii to turbot larvae. The bacteria were taken up endosomally from the brush border of the epithelium. They were transported to the lamina propria and onwards to the bloodstream and other organs. These findings contrast with our observations. The fact that we saw bacteria seemingly attached to the larval microvilli does not necessarily imply that they enter the fish by this route. Olafsen \& Hansen (1992) showed endocytosis of bacteria by epithelial cells in the hindguts of 4 to $6 \mathrm{~d}$ old cod larvae and 10 to $12 \mathrm{~d}$ old herring Clupea harengus larvae. They also found intact bacterial antigens in columnar epithelial cells in the foregut of $4 \mathrm{~d}$ old cod yolk-sac larvae. It is possible that Grisez et al. (1996) detected merely the endocytosis of dissolved LPS rather than whole bacteria, since most antisera are designed to react on the LPS of bacteria. In our opinion, this does not provide conclusive evidence of the infection route in turbot.

Acknowlegements. This work was partially funded by the Research Council of Norway (Project No 158882/110). We thank I. Wangen for help with the preservation of larvae.

\section{LITERATURE CITED}

Baudin Laurencin F, Germon E (1987) Experimental infection of rainbow trout, Salmo gairdneri R., by dipping in suspensions of Vibrio anguillarum: ways of bacterial penetration; influence of temperature and salinity. Aquaculture 67:203-272

> Bergh Ø, Hansen GH, Taxt RE (1992) Experimental infection of eggs and yolk-sac larvae of halibut, Hippoglossus hippoglossus L. J Fish Dis 15:379-391

> Bergh Ø, Hjeltnes B, Skiftesvik AB (1997) Experimental infection of turbot Scophthalmus maximus and halibut Hip- 
poglossus hippoglossus yolk sac larvae with Aeromonas salmonicida subsp. salmonicida. Dis Aquat Org 29:13-20

Bricknell I, Dalmo RA (2005) The use of immunostimulants in fish larval aquaculture. Fish Shellfish Immunol 19: 457-472

Bricknell IR, Bron JE, Bowden TJ (2006) Diseases of gadoid fish in cultivation: a review. ICES J Mar Sci 63:253-266

Egidius E (1987) Vibriosis - pathogenicity and pathology - a review. Aquaculture 67:15-28

Garcia T, Otto K, Kjelleberg S, Nelson DR (1997) Growth of Vibrio anguillarum in salmon intestinal mucus. Appl Environ Microbiol 63:1034-1039

Grisez L, Chair M, Sorgeloos P, Ollevier F (1996) Mode of infection and spread of Vibrio anguillarum in turbot Scophthalmus maximus larvae after oral challenge through live feed. Dis Aquat Org 26:181-187

Hansen GH, Olafsen JA (1989) Bacterial colonization of cod (Gadus morhua L.) and halibut (Hippoglossus hippoglossus) eggs in marine aquaculture. Appl Environ Microbiol 55:1435-1446

Kanno T, Nakai T, Muroga K (1989) Mode of transmission of vibriosis among ayu Plecoglossus altivelis. J Aquat Anim Health 1:2-6

Kjørsvik E, van der Meeren T, Kryvi H, Arnfinnson J, Kvenseth PG (1991) Early development of the digestive tract of cod larvae, Gadus morhua L., during start-feeding and starvation. J Fish Biol 38:1-15

Knappskog DH, Rødseth OM, Slinde E, Endresen C (1993) Immunochemical analyses of Vibrio anguillarum strains isolated from cod, Gadus morhua L., suffering from vibriosis. J Fish Dis 16:327-338

Korsnes K, Nicolaisen O, Skår CK, Nerland AH, Bergh Ø (2006) Bacteria in the gut of juvenile cod Gadus morhua fed live feed enriched with four different commercial diets. ICES J Mar Sci 63:296-301

Larsen JL (1984) Vibrio anguillarum - influence of temperature, $\mathrm{pH}, \mathrm{NaCl}$ concentration and incubation time on growth. J Appl Bacteriol 57:237-246

Larsen JL, Pedersen K, Dalsgaard I (1994) Vibrio anguillarum - serovars associated with vibriosis in Fish. J Fish Dis 17:259-267

Mangor-Jensen A, Adoff GR (1987) Drinking activity of the newly hatched larvae of cod Gadhus morhua L. Fish Physiol Biochem 3:99-103

Mikkelsen H, Lund V, Martinsen LC, Gravingen K, Schrøder MB (2007) Variability among Vibrio anguillarum O2 isolates from Atlantic cod (Gadus morhua L.): characterisation and vaccination studies. Aquaculture 266:16-25

Milton DL, O'Toole R, Hörstedt P, Wolf-Watz H (1996) Flagellin A is essential for the virulence of Vibrio anguillarum. J Bacteriol 178:1310-1319

O'Toole R, Milton DL, Wolf-Watz H (1996) Chemotactic motility is required for invasion of the host by the fish pathogen Vibrio anguillarum. Mol Microbiol 19:625-637

O'Toole R, Lundberg S, Fredriksson SA, Jansson A, Nilsson B, Wolf-Watz H (1999) The chemotactic response of Vibrio anguillarum to fish intestinal mucus is mediated by a combination of multiple mucus components. J Bacteriol 181:4308-4317

> Oeding P (1957) Agglutinability of pyrogenic staphylococci at various conditions. Acta Pathol Microbiol Scand 41: $310-324$

> Olafsen JA, Hansen GH (1992) Intact antigen uptake in intestinal epithelial cells of marine fish larvae. J Fish Biol 40:141-156

> Olsson JC, Jöborn A, Westerdahl A, Blomberg L, Kjelleberg S, Conway PL (1996) Is the turbot, Scophthalmus maximus
(L), intestine a portal of entry for the fish pathogen Vibrio anguillarum? J Fish Dis 19:225-234

Ormonde P, Hörstedt P, O'Toole R, Milton DL (2000) Role of motility in adherence to and invasion of a fish cell line by Vibrio anguillarum. J Bacteriol 182:2326-2328

Pedersen T, Falk-Petersen IB (1992) Morphological changes during metamorphosis in cod Gadus morhua L, with particular reference to the development of the stomach and pyloric ceca. J Fish Biol 41:449-461

Pedersen K, Grisez L, van Houdt R, Tiainen T, Ollevier F, Larsen JL (1999) Extended serotyping scheme for Vibrio anguillarum with the definition and characterization of seven provisional O-serogroups. Curr Microbiol 38: 183-189

Planas M, Perez-Lorenzo M, Vazquez JA, Pintado J (2005) A model for experimental infections with Vibrio (Listonella) anguillarum in first feeding turbot (Scophthalmus maximus L.) larvae under hatchery conditions. Aquaculture 250:232-243

> Planas M, Perez-Lorenzo M, Hjelm M, Gram L, Fiksdal IU, Bergh Ø, Pintado J (2006) Probiotic effect in vivo of Roseobacter strain 27-4 against Vibrio (Listonella) anguillarum infections in turbot (Scophthalmus maximus L.) larvae. Aquaculture 255:323-333

Rice WR (1989) Analyzing tables of statistical tests. Evolution 43:223-225

> Rombough PJ (1998) The respiratory development of Atlantic salmon. 2. Partitioning of oxygen uptake among gills, yolk sac and body surfaces. J Exp Biol 201:1763-1769

- Samuelsen OB, Nerland AH, Jorgensen T, Schrøder MB, Svåsand T, Bergh Ø (2006) Viral and bacterial diseases of Atlantic cod Gadus morhua, their prophylaxis and treatment: a review. Dis Aquat Org 71:239-254

Sandlund N, Torkildsen L, Magnesen T, Mortensen S, Bergh $\varnothing$ (2006) Immunohistochemistry of great scallop Pecten maximus larvae experimentally challenged with pathogenic bacteria. Dis Aquat Org 69:163-173

Sandlund N, Bergh $\varnothing$ (in press) Screening and characterisation of potentially pathogenic bacteria associated with Atlantic cod Gadus morhua larvae: bath challenge trials using a multidish system. Dis Aquat Org

Schrøder MB, Villena AJ, Jørgensen TØ (1998) Ontogeny of lymphoid organs and immunoglobulin-producing cells in Atlantic cod (Gadus morhua L.). Dev Comp Immunol 22:507-517

Smith PA, Rojas ME, Guajardo A, Contreras J, Morales MA, Larenas J (2004) Experimental infections of coho salmon Oncorhynchus kisutch by exposure of skin, gills and intestine with Piscirickettsia salmonis. Dis Aquat Org 61:53-57

Spanggaard B, Huber I, Nielsen J, Nielsen T, Gram L (2000) Proliferation and location of Vibrio anguillarum during infection of rainbow trout, Oncorhynchus mykiss (Walbaum). J Fish Dis 23:423-427

Svåsand T, Otterå HM, Taranger GL (2004) Atlantic cod. In: Moksness E, Kjørsvik E, Olsen Y (eds) Culture of cold-water marine fish. Blackwell Publishing, Oxford, p 433-444

Thompson FL, Iida T, Swings J (2004) Biodiversity of vibrios. Microbiol Mol Biol Rev 68:403-431

Vadstein O (1997) The use of immunostimulation in marine larviculture: possibilities and challenges. Aquaculture 155:401-417

Verner-Jeffreys DW, Shields RJ, Birkbeck TH (2003) Bacterial influences on Atlantic halibut Hippoglossus hippoglossus yolk-sac larval survival and start-feed response. Dis Aquat Org 56:105-113

Vine NG, Leukes WD, Kaiser H, Daya S, Baxter J, Hecht T 
(2004) Competition for attachment of aquaculture candidate probiotic and pathogenic bacteria on fish intestinal mucus. J Fish Dis 27:319-326

Wells P, Pinder A (1996a) The respiratory development of Atlantic salmon. 1. Morphometry of gills, yolk sac and body surface. J Exp Biol 199:2725-2736

Wells P, Pinder A (1996b) The respiratory development of Atlantic salmon. 2. Partitioning of oxygen uptake among gills, yolk sac and body surfaces. J Exp Biol 199:

Editorial responsibility: John Austin,

Oldendorf/Luhe, Germany
$2737-2744$

Yan QP, Chen Q, Ma S, Zhuang ZX, Wang XR (2007) Characteristics of adherence of pathogenic Vibrio alginolyticus to the intestinal mucus of large yellow croaker (Pseudosciaena crocea). Aquaculture 269:21-30

Yúfera M, Fernandez-Diaz C, Vidaurreta A, Cara JB, Moyano FJ (2004) Gastrointestinal pH and development of the acid digestion in larvae and early juveniles of Sparus aurata. (Pisces: Teleostei). Mar Biol 144:863-869

Submitted: December 3, 2007; Accepted: April 15, 2008 Proofs received from author(s): May 29, 2008 